\title{
Kadın Girişimci Profilinin Belirlenmesine Yönelik TR72 Bölgesinde Bir Araştırma*
}

$\ddot{\mathbf{O} z}$

Bu araştırma, kadın girişimcilerin profillerini, seçilmiş bazı değişkenler açısından ortaya çıkarmak amacı ile yapılmıştır. Çalışmada, kadınların girişimci özellikleri ve girişimcilik deneyimleri üzerinde durulmuştur. Araştırmanin evrenini Kayseri, Yozgat ve Sivas illerinde faaliyet gösteren Ticaret ve Sanayi odalarına kayıtlı 244 kadın girişimci oluşturmaktadır. Bu çalışmada, toplam 59 maddeden oluşan anket formu kullanılmış, veriler frekans tablolarına dönüştürülmüştür. Araştırma sonucunda, kadın girişimcilerin sosyo-ekonomik profilleri, işletmeleri ve girişimcilik faaliyetlerine ilişskin mevcut durum ortaya koyulmuştur.
\end{abstract}

Anahtar Kelimeler: Kadın, Girişimci, Giriş̧imcilik, Kadın Giriş̧imci.

\section{A Study in the TR72 Region to Determine the Profile of Women Entrepreneurs}

\begin{abstract}
This research has been carried out to reveal the profiles of women entrepreneurs in terms of some selected variables. In this study, the entrepreneurial characteristic of women and entrepreneurship experiences were emphasized. The universe of the research is 244 women entrepreneurs registered in the Chambers of Commerce and Industry operating in Kayseri, Yozgat and Sivas. In this study, a questionnaire consisting of 59 items was used, and the data were transformed into frequency tables. As a result of the research, the socio-economic profiles of women entrepreneurs and the current situation regarding their businesses and entrepreneurship activities were revealed.
\end{abstract}

Keywords: Woman, Entrepreneur, Entrepreneurship, Woman Entrepreneur.

\footnotetext{
* Bu çalışma Prof. Dr. Berrin FÍLIZZ̈̈Z danışmanlığında, Dilara YARAŞ tarafından hazırlanan "Kadın Girişimciliği ve TR72 Bölgesi'nde Kadın Girişimciliği Profili" başlıklı Yüksek Lisans Tezinden üretilmiştir.

** ORCID Sivas Cumhuriyet Üniversitesi, İ.İ.B.F, İşletme Bölümü, bfilizoz@hotmail.com

*** ORCID İşletme Bilimi Uzmanı, dilarakocmen@hotmail.com
} 


\section{Extended Abstract}

In this research, the characteristics of women entrepreneurs and enterprises in Sivas, Kayseri and Yozgat provinces were examined and the profiles of women entrepreneurs in these provinces were tried to be determined. Participants of the research consist of 244 women entrepreneurs registered in the Chambers of Commerce and Industry operating in Kayseri, Yozgat and Sivas provinces. The outcome of the study determined the current situation, according to the selected criteria regarding the socio-economic profiles, businesses, and entrepreneurship activities of women entrepreneurs.

According to the results of the research, most women entrepreneurs in Sivas, Kayseri and Yozgat have small-scale businesses. The principal cause of entrepreneurship activities that women have started is the desire to provide financial support to the family and to work independently. It has been determined that women entrepreneurs in all provinces have a higher income after entrepreneurship. These rates show that women make economic gains in their business models. When sectoral terms take into account, it is seen that the majority of women entrepreneurs in the TR72 region are involved in jobs that are defined as specific to women (restaurant management, clothing stores, home cooking, etc.) and in-service sectors aimed at meeting the needs of women (hairdresser, beauty salon, etc.). Regionally, women's entrepreneurship is an entrepreneurial activity away from the industrial sector. One could say the reason for that might be male-dominated entrepreneurial structure in the fields of industry and production in the provinces, studied.

In general, it is seen that women entrepreneurs receive substantial family support in terms of establishing business and family balance. Besides, almost half of the women entrepreneurs stated that they were subjected to gender discrimination, and a considerable proportion of women entrepreneurs expressed that they regard as a stranger in their environment. For women entrepreneurs to engage in entrepreneurship activities in different sectors, it is necessary to develop strategies and policies to encourage and support women's entrepreneurship. Also, training can be provided to women, so that they can be directed to entrepreneurship in the industrial sector. Supporting women in business effects on employment and economic consequences which have great importance for both the regional and the national economy. With women taking a more active role in entrepreneurship, gender inequality between men and women may decrease and the patriarchal structure in the region might be rectifiable. In addition, support for women's entrepreneurship should be continued not only at the stage of establishing a business but also while continuing the entrepreneurial activity after establishing the business. Since Sivas, Kayseri and Yozgat provinces where the study was conducted, are close to each other in terms of cultural structure, the results of the study were found to be similar in all provinces. Regardless, future research could continue to explore an expansion of the number of attendees in 3 provinces and re-evaluated. Besides, the results can be evaluated by researching in different provinces of Anatolia and in big cities where women entrepreneurship is more common. 


\section{Giriș}

Ülkelerin ekonomik gelişmelerinin ve kalkınmalarının temel göstergelerinden biri girişimcilik faaliyetleridir. Girişimcilik faaliyetlerine önem verilmesinin temel sebepleri arasında istihdamın artırılması ve ekonomik refah düzeyinin yükseltilmesi yer almaktadır. Ayrıca girişimcilik faaliyetleri, gelecekte yaşanabilecek değişimlere karşı ihtiyaçların karşılanabilmesi adına değer yaratma süreci olarak düşünülmektedir.

Girişimcilik faaliyetlerini etkileyen birçok faktör bulunmaktadır. Bununla beraber özellikle toplumun sosyal ve kültürel yapısı girişimcilik faaliyetleri üzerinde etkili faktörlerden biri olarak görülmektedir. Özellikle erkek egemen toplumlarda girişimcilik faaliyetleri daha çok erkekler tarafından yürütülmektedir. Toplumsal cinsiyet rolleri gereği kadının ev sorumluluğunun daha fazla olması kadının iş hayatına girişini zorlaştırmaktadır.

Dünya nüfusunun yarısını oluşturan kadınlara yönelik toplumsal önyargıların ve toplumsal rollerin dayatılması kadınların iş hayatındaki varlıklarını olumsuz yönde etkilemektedir. Özellikle az gelişmiş ve gelişmekte olan ülkelerde toplumsal cinsiyet rollerinden kaynaklı iş hayatındaki ayrımcılıklar daha yüksektir. Bu durum kadınların girişimcilik faaliyetlerini olumsuz yönde etkilemektedir. Girişimcilik faaliyetinde bulunan birçok kadın ise geleneksel roller gereği ev ve iş yaşam dengesini kurmak zorundadır. Bu durum kadınların daha çok ev ekonomisine katkı sağlayacak ve ev sorumluluklarını aksatmayacak girişimcilik faaliyetlerinde bulunmalarına sebebiyet vermektedir.

Kadınların işgücüne katılımının özellikle bilgi toplumuna geçiş ile beraber arttığı söylenebilir. Ancak kadınların işgücüne katılımları ile girişimcilik faaliyetlerinde bulunmaları farklı değerlendirilmektedir. Kadın girişimciler genel olarak erkek girişimcilere göre daha az risk barındıran işlere yönelmektedirler. Mevcut piyasa koşullarında kadın girişimcilerin daha az riskli işlere yönelmeleri özellikle ev ve iş sorumluluğunu birlikte yürütmelerinden kaynaklanmaktadır (Bedük vd.,2016:6).

Bilgi toplumuna geçiş ile beraber her ne kadar kadınların işgücündeki rolleri artsa da girişimcilik aktivitelerinin sınırlı olduğunu söylemek mümkündür. Bu durum özellikle erkek egemen iş dünyasında kadınların girişimcilik faaliyetlerinin desteklenmemesi ile ifade edilebilir (Soysal, 2010a:77).

Tarih boyunca kadınların işgücüne katılımı ülkelerin gelişmişlik düzeylerine göre farklılık göstermiştir. Kadınların yalnızca belirli sektörlerde değil tüm sektörlerde işgücüne katılım göstermeleri, mikro düzeyde aile ekonomisine, makro düzeyde ise istihdama ve ülkelerin ekonomik kalkınmasına olumlu yönde etki edecektir (Özyol, 2015:1).

Kadınların girişimcilik faaliyetlerindeki en önemli faktör başarı isteğidir. Kadınların bağımsızlık ve özgürlük duygusu doğrultusunda yeni bir kariyer planlaması yapma ihtiyacı duyarak girişimcilik faaliyetlerinde bulunduğu söylenebilir. Özellikle risk alma eğilimi yüksek kadınlar başarma ihtiyacı doğrultusunda yeni iş alanları yaratabilirler. Kadınların girişimci olmalarında başarı, risk ve bağımsız olma duyguları ön planda olmakla beraber, başarılı girişimci olmalarında ise doğru karar alabilme ve geleceğini planlayabilme özelliklerinin yüksek olması gerekmektedir (Güney, 2006:34).

\section{Kadın Girişimciliğgi}

Kadın girişimciliği, kadının kendisinin veya çalıştırdığg diğer kişilerle beraber iş süreçlerini ev dışındaki bir mekânda yürütmesi ve iş sorumluluğunu üstlenmesi olarak görülür. Kadınların yapmış olduğu işlerin girişimcilik faaliyetleri adı altında değerlendirilmesi için kadının tüm iş 
süreçlerinde risk üstlenmesi ve sorumluluğu kabul etmesi gerekmektedir. Kadının eğitim almış olduğu meslek ile ilgili faaliyetlerini risk üstlenmeden başka bir kişi veya kurum sorumluluğunda yürütmesi girişimcilik olarak tanımlanmamaktadır (Soysal, 2010b:90).

Kadın girişimci, iş yerindeki tüm riski ve sorumluluğu üstlenmiş, kaynakları bir araya getirerek üretim faaliyetlerini gerçekleştiren kadın olarak tanımlanır. Kadın girişimciler piyasa şartları doğrultusunda kaynaklarını etkin bir şekilde yönetme ve üretim araçlarını aktarma faaliyetlerinde bulunurlar (Yıldırım ve Çıkmaz, 2016:978).

Kadın girişimciliği için temel alınan bazı tanımlar aşağıdaki gibi sıralanabilir. (Ballı Koca, 2015:33):

- Evinde veya ev dışı bir mekânda kendi adına kurulmuş, bir veya daha fazla iş yeri olan,

- İş sahibi olma sıfatı ile beraber tek başına veya istihdam ettiği kişilerle beraber iş faaliyetlerini sürdüren,

- Mal veya hizmet üretim sürecinde çeşitli organizasyonlar düzenleyen, dağıtım, pazarlama ve satış kanallarını yürüten,

- İşle ilgili olarak çeşitli kurum veya kuruluşlarla kendi adına faaliyetlerini sürdüren,

- İş süreçlerinin düzenlenmesinde mal ve hizmet üretiminin planlanmasında iş yeri ile ilgili çeşitli gelişmelerin sağlanmasında kendi adına karar veren,

- İş faaliyetleri sonucunda elde etmiş olduğu kazancı tüketim veya yatırıma dönüştürmede söz sahibi olan kadın şeklinde ifade edilmektedir.

Dünya nüfusunun yarısı ve küresel üretimde iş gücünün üçte biri kadındır. Potansiyel işgücünün yarısını güçlendirmek, önemli ekonomik faydalar sağlayabilir. Birçok çalışma girişimciliğin önemini ve sürekli ekonomik gelişime yönelik özellikle kadınların girişimciliğini savunmaktadır. Kadın girişimciliğinin gelişimi, büyük ölçüde içsel ve girişimcilerin kişisel özellikleri, aile işleri, hükümet ve diğer destekleyici örgütsel katılımlar gibi dış etkenlere bağlıdır (Goyal ve Yadav, 2014:69).

Kadın girişimcilerin genel olarak ekonomik faaliyetleri incelendiğinde kadın girişimcilerin erkek girişimcilerden farklı olarak çoğunlukla kayıt dışı olarak nitelendirilebilecek şekilde girişimcilik faaliyetleri yürüttükleri söylenebilir. Kadın girişimciler çoğunlukla kişisel beklentilerini ön planda tutarak girişimcilik faaliyetlerini yürütmeye çalışmaktadırlar. Kadınlar yalnızca firmanın başarısını değil aynı zamanda kendi kişisel görüşlerini ve sosyo-kültürel çevrelerinin temel değerlerini göz önünde bulundurarak faaliyetlerini yürütmeye çalışırlar. Erkek girişimciler daha çok kar odaklı girişimcilik faaliyetleri yürütürken, kadın girişimciler için sosyal itibar daha fazla ön planda olmaktadır. Kadın girişimciler özellikle risk alma konusunda erkeklere göre daha temkinli yaklaşmaktadır (Soysal, 2010a:74).

Kadın girişimcilerin başarıya ulaşmalarında gerekli olan şartlar aşağıdaki gibi sıralanabilir (Yıldırım ve Çıkmaz, 2016:978):

- Kadın girişimciler özellikle devletin çeşitli kurumları tarafından desteklenmelidir. Devlet politikaları çerçevesinde kadın girişimcilere verilen maddi destekler kadın girişimcilerin yatırım imkanlarını olumlu yönde etkileyecektir.

- Kadın girişimcilerin başarısında ev dışı bir ortamda kendilerine ait bir iş yerinin var olması önemlidir. 
- Kadın girişimcinin işyerinde kendisinin veya kendisi ile beraber farklı çalışanlar bulunması gerekir.

- Kadın girişimcilerin başarısında pazarlama, dağıtım, satış gibi faaliyetlerin işletme içinde etkin bir şekilde gerçekleştirilmesi gerekmektedir.

- İş süreçleri ile ilgili kararların etkin bir şekilde verilmesi ve işin devamlılığg için gerekli stratejilerin belirlenmesi ve uygulanması kadın girişimcilerin sorumluluğu altındadır.

- Kadın girişimciler iş süreçleri sonucunda elde edilen kazancın sorumluluğunu ellerinde bulundururlar.

\subsection{Kadın Girişimciliğin Önemi}

Kadın girişimcilerin ekonomik faaliyetleri dünya ekonomilerinin gelişmesi ve büyümesinde önemli rol üstlenmektedir. Dünyada özellikle gelişmiş ülkelerde kadın girişimcilerin başarılarının erkek girişimcilerle eşit ve en az erkek girişimciler kadar etkili olduğu ifade edilmektedir. Kadın girişimcilerin ekonomik gelişme ve büyümede önemli roller üstlenmesi kadın girişimciliğine yönelik faaliyetleri daha önemli hale getirmektedir (Rao vd.,2013:136).

Kadın girişimcilerin genel olarak ülkeye ve aileye sağlamış oldukları makro ve mikro düzeydeki katkıları aşağıda sıralanmıştır (Şekerler, 2006:123; Aydın ve Çam, 2016:229-230):

Kadın girişimcilerin makro düzeydeki katkıları:

- Vergi ödeme

- İstihdam yaratma

- Milli gelire katkı sağlama

Kadın girişimcilerin mikro düzeydeki katkıları:

- Ailenin maddi imkanlarına katk1

- Aile refahını yükseltme

- Çocukların eğitim imkanlarında yükselme sağlama

- Çocukların annelerini rol model olarak almaları

\subsection{Kadınları Girişimciliğe Yönlendiren Nedenler}

Kadın ve erkek girişimcilerin girişimci olmayı tercih etme nedenleri birbirinden farklıdır. Erkek girişimciler için girişimci olmanın en temel nedeni ekonomik beklentiler ve servet yaratmak olarak ifade edilebilecekken, kadın girişimciler için ise bağımsız çalışma ve haneye ek gelir sağlama olarak görülmektedir (Soysal, 2010a:74-75).

Kadın girişimcilerin girişimcilik faaliyetleri göstermelerinin en önemli nedenleri arasında maddi olarak bağımsızlıklarına kavuşabilme durumu yer almaktadır. Kadın girişimciler maddi olarak bağımsızlıklarını elde etmelerini takiben özel yaşamlarında ve kariyerlerinde de bağımsız hareket edebilme imkanlarına sahip olurlar. Özellikle ev sorumluluklarından bağımsız olarak hareket edebilme talebi içinde olan kadınlar girişimcilik faaliyetlerinde bulunma çabası içine girmektedir. Bağımsızlık durumu, kadın girişimcilerin faaliyetlere başlamaları için motivasyonel bir kaynak olarak değerlendirilir (Goyal ve Parkash, 2011:196). 
Kadınların girişimcilik faaliyetlerini etkileyen faktörler az gelişmiş, gelişmekte olan ve gelişmiş ülkelerde farklılık göstermektedir. Heilman ve Chen (2003) tarafından gelişmiş ülkelerde yapılan araştırmada kadınların girişimcilik faaliyetlerini etkileyen en önemli faktörün ücretli olarak çalışmak yerine kendi işinin sahibi olmanın verdiği avantaj olduğu ifade edilmektedir. Kadınlar için girişimcilik faaliyetleri yalnızca maddi gelir elde etmek ve erkeklerden bağımsız olarak özgürlüklerini sürdürmek şeklinde değil aynı zamanda profesyonel hayatlarında kendi işlerine devam etme talepleri olarak görülmektedir (Heilman ve Chen, 2003). Bununla beraber Türkiye gibi gelişmekte olan ülkelerde ise kadın girişimciliğinin temelinde, kadınların maddi açıdan erkeklerden bağımsız olma ve aile bütçesine katkı sağlama talepleri yer almaktadır (Başol, 2010).

\subsection{Kadın Girişimcilerin Yaşadıkları Sorunlar}

Kadınların iş yaşamında ve girişimcilik faaliyetlerinde yaşadıkları en önemli problem toplumsal cinsiyet ayrımcılığı olarak görülebilir. Özellikle ataerkil toplumlarda kadınlara yüklenen ev ve çocuk sorumluluğu, kadınların iş yaşamlarındaki varlıklarının önündeki en önemli engeldir. Bununla beraber kadınlara biçilen iş rolleri arasında hemşirelik, sekreterlik, öğretmenlik gibi meslekler ön plana çıkmaktadır. Kadınlara özgü olarak belirlenen bu mesleklerin temelinde toplumsal cinsiyet ayrımcılı̆̆ 1 yer almaktadır. Kadınların yükselme imkânlarının zayıf olarak görülmesi ve ev sorumluluklarının kadına yüklenmesi kadınların iş yaşamındaki başarılarının ve kariyerlerinin önündeki engeldir (Alpşahin, 2011:104).

Kadınların girişimcilik faaliyetlerindeki en önemli engeller arasında kadınların bizzat kendilerinin oluşturdukları engeller yer almaktadır. Kadınların geleneksel roller gereği daha az risk üstlenme eğilimi içinde olmaları riskli girişimcilik faaliyetlerine yönelmelerini engellemektedir. Kadınların özellikle kurtarıcı veya anne rolü ile hareket ederek fazla sorumluluk üstlenmeleri ve çeşitli ayrıntılarla fazla zaman kaybetmeleri, iş ile ilgili önemli konulara yoğunlaşmalarını engellemektedir. Bu durum kadınların girişimcilik faaliyetlerine yönelik istedikleri zamanı ve enerjiyi harcayamamalarına neden olmaktadır (Öğüt, 2006:66).

\section{Yöntem}

\subsection{Araştırmanın Amacı, Evren ve Örneklemi}

$\mathrm{Bu}$ araştırmanın amacı kadın girişimci profillerinin incelenmesidir. Araştırmanın evrenini Kayseri, Yozgat ve Sivas illerinde faaliyet gösteren kadın girişimciler oluşturmaktadır. İllerin Ticaret ve Sanayi Odalarından alınan verilere göre ilgili odalara kayıtlı aktif kadın girişimci sayıları aşağıdaki gibidir:

- Kayseri 156 kadın girişimci

- Yozgat 180 kadın girişimci

- Sivas 210 kadın girişimci

Üç ilde toplam 546 kadın girişimci bulunmaktadır. Yazıcıŏlu ve Erdoğan (2004) örneklem hesaplamalarına göre \%5 örneklem hatasında güvenirlilik için en az 240 katılımcıya ulaşmak gerekmektedir. Araştırmada Kayseri, Yozgat ve Sivas İlleri için kadın girişimci sayılarına göre alınması gereken örneklem sayıları hesaplanmıştır. Bu doğrultuda iller için ulaşılan kadın girişimci sayıları şu şekilde oluşmuştur:

- Kayseri 70 kadın girişimci 
- Yozgat 80 kadın girişimci

- Sivas 94 kadın girişimci

Toplamda 244 kadın girişimciye ulaşılmıştır.

\subsection{Veri Toplama Yöntemi}

Araştırmada verilerin toplanmasında anket formu kullanılmıştır. Anket formları online olarak ve yüz yüze görüşmeler ile katılımcılara ulaştırılmıştır. Ankette toplam 59 soru bulunmaktadır. 20 soru açık uçlu ve 39 soru kapalı uçlu olarak hazırlanmıştır.

\section{Bulgular}

Araştırmaya katılan kadın girişimcilerin yaş ve eğitim durumları incelenmiştir. Buna göre Yozgat'ta kadın girişimcilerin Kayseri ve Sivas'a göre daha genç yaş aralığında olduğu görülmektedir. Eğitim durumu açısından ise üç ilde de kadın girişimcilerin büyük oranının lise mezunu olduğu görülmüştür.

Tablo 1: Yaş ve Eğitim Durumuna Yönelik Bulgular

\begin{tabular}{|c|c|c|c|c|c|c|}
\hline & \multicolumn{2}{|c|}{ Kayseri } & \multicolumn{2}{|c|}{ Yozgat } & \multicolumn{2}{|c|}{ Sivas } \\
\hline & Frekans & $\%$ & Frekans & $\%$ & Frekans & $\%$ \\
\hline \multicolumn{7}{|l|}{ Yaş } \\
\hline $20-25$ & 22 & 31,4 & 35 & 43,8 & 32 & 34,0 \\
\hline $26-30$ & 27 & 38,6 & 27 & 33,8 & 36 & 38,3 \\
\hline $31-35$ & 17 & 24,3 & 11 & 13,7 & 20 & 21,3 \\
\hline $36-40$ & 4 & 5,7 & 4 & 5,0 & 4 & 4,3 \\
\hline 41 ve üzeri & & & 3 & 3,7 & 2 & 2,1 \\
\hline \multicolumn{7}{|l|}{ Eğitim Durumu } \\
\hline İlköğretim/Ortaöğretim & 2 & 2,9 & 5 & 6,2 & 4 & 4,2 \\
\hline Lise & 38 & 54,3 & 48 & 60,0 & 51 & 54,3 \\
\hline Önlisans & 7 & 10,0 & 7 & 8,8 & 9 & 9,6 \\
\hline Lisans & 12 & 17,1 & 15 & 18,8 & 18 & 19,1 \\
\hline Yüksek Lisans & 11 & 15,7 & 5 & 6,2 & 12 & 12,8 \\
\hline
\end{tabular}


Tablo 2: Anne ve Baba Eğitim Durumuna Yönelik Bulgular

\begin{tabular}{|c|c|c|c|c|c|c|}
\hline & \multicolumn{2}{|c|}{ Kayseri } & \multicolumn{2}{|c|}{ Yozgat } & \multicolumn{2}{|c|}{ Sivas } \\
\hline & Frekans & $\%$ & Frekans & $\%$ & Frekans & $\%$ \\
\hline \multicolumn{7}{|c|}{ Anne Eğitim Durumu } \\
\hline Okur-Yazar & 6 & 8,6 & 2 & 2,5 & 6 & 6,4 \\
\hline İlköğretim & 31 & 44,3 & 43 & 53,8 & 44 & 46,8 \\
\hline Lise & 24 & 34,3 & 23 & 28,8 & 31 & 33,0 \\
\hline Önlisans & 2 & 2,8 & 5 & 6,2 & 4 & 4,2 \\
\hline Lisans & 7 & 10,0 & 7 & 8,7 & 9 & 9,6 \\
\hline \multicolumn{7}{|c|}{ Baba Eğitim Durumu } \\
\hline Okur-Yazar & 9 & 12,9 & 7 & 8,8 & 9 & 9,6 \\
\hline İlköğretim & 23 & 32,9 & 32 & 40,0 & 33 & 35,1 \\
\hline Lise & 26 & 37,1 & 28 & 35,0 & 35 & 37,2 \\
\hline Önlisans & 2 & 2,9 & 5 & 6,2 & 4 & 4,2 \\
\hline Lisans & 8 & 11,4 & 4 & 5,0 & 9 & 9,6 \\
\hline Yüksek Lisans & 2 & 2,8 & 4 & 5,0 & 4 & 4,3 \\
\hline
\end{tabular}

Araştırmaya katılan kadın girişimcilerin anne ve babalarının eğitim düzeyi yönüyle bakıldığında kadın girişimcilerin babalarının eğitim düzeyi Kayseri ve Sivas'ta lise düzeyinde iken, Yozgat'ta ilköğretim düzeyinde, annelerinin eğitim düzeyi ise her üç ilde ilköğretim seviyesindedir.

Tablo 3: Medeni Durum, Eşin Eğitim Durumu ve Çocuk Durumuna Yönelik Bulgular

\begin{tabular}{|c|c|c|c|c|c|c|}
\hline & \multicolumn{2}{|c|}{ Kayseri } & \multicolumn{2}{|c|}{ Yozgat } & \multicolumn{2}{|c|}{ Sivas } \\
\hline & Frekans & $\%$ & Frekans & $\%$ & Frekans & $\%$ \\
\hline \multicolumn{7}{|l|}{ Medeni Durum } \\
\hline Bekar & 24 & 34,2 & 34 & 42,5 & 36 & 38,3 \\
\hline Boşanmış/dul & 2 & 2,9 & 4 & 5,0 & 5 & 5,3 \\
\hline Evli & 44 & 62,9 & 42 & 52,5 & 53 & 56,4 \\
\hline \multicolumn{7}{|c|}{ Eşin Eğitim Durumu } \\
\hline Lise & 28 & 40,0 & 21 & 26,2 & 30 & 31,9 \\
\hline Önlisans & 7 & 10,0 & 8 & 10,0 & 10 & 10,6 \\
\hline Lisans & 6 & 8,6 & 12 & 15,0 & 10 & 10,6 \\
\hline Yüksek Lisans & 5 & 7,1 & 4 & 5,0 & 5 & 5,3 \\
\hline \multicolumn{7}{|c|}{ Çocuk Durumu } \\
\hline Evet & 38 & 54,3 & 34 & 42,5 & 48 & 51,1 \\
\hline Hayır & 32 & 45,7 & 46 & 57,5 & 46 & 48,9 \\
\hline
\end{tabular}

Araştırmaya katılan kadın girişimcilerin medeni durumu, eşlerinin eğitim durumu ve çocuk sayılarına yönelik durumuna bakıldığında her üç ilde de kadın girişimcilerin çoğunluğunun evli olduğu görülmektedir. Kayseri'de kadın girişimcilerin \%40'ının, Yozgat'ta $\% 26,2$ 'sinin ve Sivas'ta \%31,9'unun eşi lise mezunudur. Çocuk durumu incelendiğinde ise Kayseri'de kadın girişimcilerin \%54,3'ü, Sivas'ta \%51,1'i çocuk sahibi iken, Yozgat'taki kadın 
girişimcilerin \%57,5'i çocuk sahibi değildir. Yozgat'taki kadın girişimcilerin Sivas ve Kayseri'deki kadın girişimcilere göre yaşlarının daha küçük olması nedeniyle çocuk sahibi olma oranlarının daha düşük olduğu söylenebilir. Yine her üç ilde kadın girişimcilerin büyük çoğunluğunun evli olması, eşlerinin girişimcilik konusunda desteklerinin olduğu şeklinde yorumlanabilir.

Tablo 4: Yabancı Dil Bilme ve Aktif Bilgisayar Kullanma Durumuna Yönelik Bulgular

\begin{tabular}{|c|c|c|c|c|c|c|}
\hline & \multicolumn{2}{|c|}{ Kayseri } & \multicolumn{2}{|c|}{ Yozgat } & \multicolumn{2}{|c|}{ Sivas } \\
\hline & Frekans & $\%$ & Frekans & $\%$ & Frekans & $\%$ \\
\hline \multicolumn{7}{|c|}{ Yabancı Dil Bilme Durumu } \\
\hline Evet & 17 & 24,3 & 24 & 30,0 & 24 & 25,5 \\
\hline Hayır & 53 & 75,7 & 56 & 70,0 & 70 & 74,5 \\
\hline \multicolumn{7}{|c|}{ Aktif Bilgisayar Kullanma Durumu } \\
\hline Evet & 64 & 91,4 & 70 & 87,5 & 86 & 91,5 \\
\hline Hayır & 6 & 8,6 & 10 & 12,5 & 8 & 8,5 \\
\hline
\end{tabular}

Kadın girişimcilerin yabancı dil bilme ve aktif bilgisayar kullanma durumuna yönelik bulgular incelendiğinde, Kayseri'de \%75,7, Yozgat'ta \%70 ve Sivas'ta \%74,5 oranında kadın girişimcinin yabancı dil bilmediği görülmektedir. Bu durum kadın girişimcilerin eğitim düzeyi ile ilişkilendirilebilir. Aktif bilgisayar kullanımı açısından Kayseri'de \%91,4, Yozgat'ta \%87,5 ve Sivas'ta \%91,5 oranında kadın girişimcinin aktif bilgisayar kullandığı görülmektedir. Burada aktif bilgisayar kullanımı kavramından kadın girişimcilerin sosyal medya kullanımını algılama olasılığı göz ardı edilmemelidir.

Tablo 5: Girişimcilik Öncesi Meslek ve Gelir Durumuna Yönelik Bulgular

\begin{tabular}{|c|c|c|c|c|c|c|}
\hline & \multicolumn{2}{|c|}{ Kayseri } & \multicolumn{2}{|c|}{ Yozgat } & \multicolumn{2}{|c|}{ Sivas } \\
\hline & Frekans & $\%$ & Frekans & $\%$ & Frekans & $\%$ \\
\hline \multicolumn{7}{|c|}{ Girişimcilik Öncesi Meslek } \\
\hline Çalışmıyor & 25 & 35,7 & 26 & 32,5 & 34 & 36,2 \\
\hline Esnaf & 4 & 5,7 & 7 & 8,8 & 7 & 7,4 \\
\hline Memur & 5 & 7,1 & 3 & 3,7 & 5 & 5,3 \\
\hline Öğrenci & 2 & 2,9 & 3 & 3,7 & 2 & 2,1 \\
\hline Özel Sektör Çal. & 34 & 48,6 & 41 & 51,25 & 46 & 49 \\
\hline \multicolumn{7}{|c|}{ Girişimcilik Öncesi Gelir Durumu } \\
\hline Eşit & 26 & 37,1 & 32 & 40,0 & 37 & 39,4 \\
\hline Gelir fazla & 10 & 14,3 & 14 & 17,5 & 14 & 14,9 \\
\hline Gider fazla & 34 & 48,6 & 34 & 42,5 & 43 & 45,7 \\
\hline
\end{tabular}

Kadın girişimcilerin girişimcilik öncesi meslek ve gelir durumuna yönelik bulgular incelendiğinde, her üç ilde de kadınların girişimcilik öncesinde çalışmadıkları ve girişimcilik öncesinde giderlerinin gelirlerinden daha fazla olduğu tespit edilmiştir. Buna göre kadınların girişimcilik faaliyetlerine yönelmelerinin nedeni istedikleri gibi harcama yapabilecekleri ekonomik gelire sahip olma ve aile bütçesine katkı sunma olarak ifade edilebilir. 
Tablo 6: Girişimcilik Öncesi ve Sonrası Aylık Gelir Durumu

\begin{tabular}{|l|c|c|c|c|c|c|c|c|c|}
\hline & \multicolumn{3}{|c|}{ Kayseri } & \multicolumn{3}{c|}{ Yozgat } & \multicolumn{3}{c|}{ Sivas } \\
\hline & Min. & Maks. & Ort. & Min. & Maks. & Ort. & Min. & Maks. & Ort. \\
\hline $\begin{array}{l}\text { Girişimcilik Öncesi } \\
\text { Aylık Gelir }\end{array}$ & 0 & 12.000 & 2.979 & 0 & 15.000 & 2.772 & 0 & 11.000 & 2.987 \\
\hline $\begin{array}{l}\text { Girişimcilik Sonrası } \\
\text { Aylık Gelir }\end{array}$ & 0 & 21.000 & 5.895 & 0 & 23.000 & 6.279 & 0 & 25.000 & 6.314 \\
\hline
\end{tabular}

Girişimcilik öncesi ve sonrası aylık gelir durumu incelendiğinde, girişimcilik sonrasında en fazla aylık gelir ortalamasına 6.314 TL ile Sivas ilinde faaliyet gösteren kadın girişimcilerin sahip oldukları tespit edilmiştir. Söz konusu gelirler tarafımızca oldukça yüksek görünse de tablo anketlere verilen cevaplar doğrultusunda oluşturulmuştur. Burada kadın girişimcilerin gelir düzeyini yüksek gösterme ve ekonomik yetersizlik düşüncesi ile girişimciliğe yöneldikleri algısını yok etme isteğinin olduğu kadar, hane halkı gelirini girişimcilik öncesi kendi gelirleri gibi düşünmeleri de söz konusu olabilir.

Tablo 7: Girişimcilik Sonrası Aylık Gelir Durumuna Yönelik Bulgular

\begin{tabular}{|l|c|c|c|c|c|c|}
\hline & \multicolumn{2}{|c|}{ Kayseri } & \multicolumn{2}{c|}{ Yozgat } & \multicolumn{2}{c|}{ Sivas } \\
\hline & Frekans & \% & Frekans & \% & Frekans & \% \\
\hline Eşit & 15 & 21,4 & 19 & 23,75 & 21 & 22,3 \\
\hline Gelir fazla & 38 & 54,3 & 43 & 53,75 & 50 & 53,2 \\
\hline Gider fazla & 17 & 24,3 & 18 & 22,5 & 23 & 24,5 \\
\hline
\end{tabular}

Kadın girişimcilerin girişimcilik sonrası aylık gelir durumuna yönelik bulgular incelendiğinde, tüm illerdeki kadın girişimcilerin girişimcilik sonrasında gelirinin daha fazla olduğu tespit edilmiştir. Bu oranlar kadınların girişimcilik faaliyetlerinde ekonomik olarak önemli katkılar sağladığını göstermektedir.

Tablo 8: Mesleki Eğitim, Girişimcilik Eğitimi, Girişimcilik Faaliyetinde Bulunma Durumuna Yönelik Bulgular

\begin{tabular}{|c|c|c|c|c|c|c|}
\hline & \multicolumn{2}{|c|}{ Kayseri } & \multicolumn{2}{|c|}{ Yozgat } & \multicolumn{2}{|c|}{ Sivas } \\
\hline & Frekans & $\%$ & Frekans & $\%$ & Frekans & $\%$ \\
\hline \multicolumn{7}{|c|}{ Mesleki Eğitim Kurslarına Katılma Durumu } \\
\hline Evet & 59 & 84,3 & 68 & 85,0 & 80 & 85,1 \\
\hline Hayır & 11 & 15,7 & 12 & 15,0 & 14 & 14,9 \\
\hline \multicolumn{7}{|c|}{ Girişimcilik Eğitimine Katılma Durumu } \\
\hline Evet & 55 & 78,6 & 62 & 77,5 & 74 & 78,7 \\
\hline Hayır & 15 & 21,4 & 18 & 22,5 & 20 & 21,3 \\
\hline \multicolumn{7}{|c|}{ İşletmeyi Açmadan Önce Girişimcilik Faaliyetinde Bulunma Durumu } \\
\hline Evet & 5 & 7,1 & 3 & 3,8 & 5 & 5,3 \\
\hline Hayır & 65 & 92,9 & 77 & 96,2 & 89 & 94,7 \\
\hline
\end{tabular}

Kadın girişimcilerin mesleki eğitim, girişimcilik eğitimi, girişimcilik faaliyetinde bulunma durumuna yönelik bulgular incelendiğinde, kadınların mesleki eğitim kurslarına ve girişimcilik eğitimine katıldığı tespit edilmiştir. İşletmeyi açmadan önce girişimcilik faaliyetinde bulunma durumuna bakıldığında, tüm illerde büyük oranda işletmeyi açmadan önce girişimcilik faaliyetinde bulunulmadığı görülmüştür. Bu açıdan değerlendirildiğinde kadınların girişimcilik deneyimleri olmadan girişimcilik faaliyetlerine yönelmelerinde, kadın 
girişimcilere yönelik teşviklerin ve bu teşvikler nedeniyle aile üyelerinin desteğinin etkisi olduğu söylenebilir.

Tablo 9: Ailede Başka Girişimci Olma Durumuna Yönelik Bulgular

\begin{tabular}{|l|l|l|l|l|l|l|}
\hline & \multicolumn{2}{|c|}{ Kayseri } & \multicolumn{2}{c|}{ Yozgat } & \multicolumn{2}{c|}{ Sivas } \\
\hline & Frekans & \% & Frekans & \% & Frekans & \% \\
\hline Evet & 31 & 44,3 & 37 & 46,2 & 44 & 46,8 \\
\hline Hayır & 39 & 55,7 & 43 & 53,8 & 50 & 53,2 \\
\hline
\end{tabular}

Ailede başka girişimci olma durumuna yönelik bulgular incelendiğinde Kayseri'de $\% 55,7$, Yozgat'ta \%53,8 ve Sivas'ta \%53,2 oranında ailede başka girişimci olmadığ belirtilmiştir. Bu oranlara göre ankete katılan kadın girişimcilerin yarısından fazlasının aileleri için örnek teşkil edebileceği ve girişimcilik kültürünün yaygınlaşmasında rol oynayacağ söylenebilir.

Tablo 10: İşletmenin Bulunduğu Sektör ve Personel Sayısına Yönelik Bulgular

\begin{tabular}{|c|c|c|c|c|c|c|}
\hline & \multicolumn{2}{|c|}{ Kayseri } & \multicolumn{2}{|c|}{ Yozgat } & \multicolumn{2}{|c|}{ Sivas } \\
\hline & Frekans & $\%$ & Frekans & $\%$ & Frekans & $\%$ \\
\hline \multicolumn{7}{|l|}{ İşletmenin Bulunduğu Sektör } \\
\hline G1da & 12 & 17,1 & 15 & 18,8 & 19 & 20,2 \\
\hline Kişisel bakım (Kuaför, güzellik merkezi vb.) & 10 & 14,3 & 12 & 15,0 & 14 & 14,9 \\
\hline Mobilya, beyaz eşya & 1 & 1,4 & 2 & 2,5 & 3 & 3,2 \\
\hline $\begin{array}{l}\text { Büro (Muhasebe, Mühendislik, Avukat, sigorta } \\
\text { vb.) }\end{array}$ & 5 & 7,1 & 11 & 13,5 & 11 & 11,7 \\
\hline Temizlik & 1 & 1,4 & 2 & 2,5 & 3 & 3,2 \\
\hline Tekstil & 12 & 17,1 & 18 & 22,5 & 22 & 23,4 \\
\hline Organizasyon, pazarlama & 4 & 5,7 & 5 & 6,3 & 7 & 7,4 \\
\hline Sağlık hizmetleri & 3 & 4,3 & 4 & 5,0 & 6 & 6,4 \\
\hline Tuhafiye, Züccaciye & 2 & 2,9 & 5 & 6,3 & 6 & 6,4 \\
\hline \multicolumn{7}{|l|}{ Çalışan Sayısı } \\
\hline Sadece kendisi & 3 & 4,3 & 4 & 5,0 & 5 & 5,3 \\
\hline $1-5$ & 40 & 57,1 & 39 & 48,8 & 44 & 46,8 \\
\hline $6-10$ & 22 & 31,4 & 21 & 26,3 & 25 & 26,6 \\
\hline 11 ve üzeri & 9 & 12,9 & 11 & 13,8 & 10 & 10,6 \\
\hline
\end{tabular}

Kadın girişimcilerin işletmelerinin bulunduğu sektör ve personel sayısına yönelik bulgular incelendiğinde, Kayseri'de \%17,1'i gıda ve \%17,1'i tekstil sektöründe, Yozgat'ta $\% 22,5$ 'i ve Sivas'ta \%23,4'ü tekstil sektöründe faaliyet göstermektedir. Ayrıca tüm illerde yüksek oranda, kadın girişimcilerin 1-5 arasında çalışanı bulunmaktadır. $\mathrm{Bu}$ oranlara bakıldığında kadınların yine kadınlara özgü olarak nitelendirilen işlerde yoğunlaştığı ve çalışan sayıları yönüyle de küçük işletme statüsünde olduğu görülmektedir.

Tablo 11: Çalışılan Banka Sayısı ve Sermaye Kaynağına Yönelik Bulgular

\begin{tabular}{|c|c|c|c|c|c|c|}
\hline & \multicolumn{2}{|c|}{ Kayseri } & \multicolumn{2}{|c|}{ Yozgat } & \multicolumn{2}{|c|}{ Sivas } \\
\hline & Frekans & $\%$ & Frekans & $\%$ & Frekans & $\%$ \\
\hline \multicolumn{7}{|c|}{ Çalışılan Banka Sayısı } \\
\hline $0-1$ & 18 & 25,7 & 31 & 38,8 & 29 & 30,9 \\
\hline $2-4$ & 42 & 60,0 & 40 & 50,0 & 52 & 55,3 \\
\hline 5 ve fazlas1 & 10 & 14,3 & 9 & 11,2 & 13 & 13,8 \\
\hline \multicolumn{7}{|c|}{ Sermaye Kaynağı/Finansman Kaynağı } \\
\hline Aile/yakın çevre & 14 & 20,0 & 13 & 16,2 & 17 & 18,1 \\
\hline Banka (kredi) & 24 & 34,2 & 28 & 35,0 & 35 & 37,3 \\
\hline Eş & 9 & 12,9 & 7 & 8,8 & 10 & 10,6 \\
\hline Kendi birikimi & 23 & 32,9 & 32 & 40,0 & 32 & 34,0 \\
\hline
\end{tabular}


Kadın girişimcilerin çalışılan banka sayısı ve sermaye kaynağına yönelik bulgular incelendiğinde, Kayseri'de \%60, Yozgat'ta $\% 50$ ve Sivas'ta $\% 53,3$ oranında kadın girişimcilerin 2-4 arasında banka ile çalıştıkları belirlenmiştir. Bununla beraber kadın girişimcilerin Kayseri'de \%34,3'ü ve Sivas'ta \%37,2'sinin sermaye kaynağı banka kredileriyken, Yozgat'ta kadın girişimcilerin \%40'ının sermaye kaynağı kendi birikimidir. Kadın girişimciler ile yapılan görüşmeler ve anket sonuçlarına istinaden Kayseri ve Sivas ilindeki kadın girişimcilerin sermayelerinin kaynağı olarak belirttikleri banka kredilerinde aile destekli kredi alımlarının olduğu düşünülmektedir.

Tablo 12: KOSGEB Desteği ve Kredi/Teşvik Kullanma Durumuna Yönelik Bulgular

\begin{tabular}{|l|c|c|c|c|c|c|}
\hline & \multicolumn{2}{|c|}{ Kayseri } & \multicolumn{2}{c|}{ Yozgat } & \multicolumn{2}{c|}{ Sivas } \\
\hline & Frekans & \% & Frekans & \% & Frekans & \% \\
\hline KOSGEB Desteği & 33 & 47,1 & 33 & 41,2 & 43 & 45,7 \\
\hline Evet & 37 & 52,9 & 47 & 58,8 & 51 & 54,3 \\
\hline Hayır & 31 & 44,3 & 37 & 46,2 & 47 & 50,0 \\
\hline Kredi/Teşvik Kullanma Durumu \\
\hline Evet & 39 & 55,7 & 43 & 53,8 & 47 & 50,0 \\
\hline Hayır & 39
\end{tabular}

KOSGEB desteği ve kredi/teşvik kullanma durumuna yönelik bulgular incelendiğinde, Kayseri'de \%52,9, Yozgat'ta \%58,8 ve Sivas'ta \%54,3 oranında kadın girişimcilerin KOSGEB desteğinden faydalanmadığ 1 tespit edilmiştir. Bununla beraber Kayseri'de \%55,7, Yozgat'ta $\% 53,8$ ve Sivas'ta $\% 50$ oranında kredi ve teşvik kullanılmadığı belirlenmiştir. Bu oranlara bakıldığında kadın girişimcilerin yarısının farklı nedenlerden dolayı teşvik ve kredi kullanımına sıcak bakmadığı söylenebilir.

Tablo 13: İşletmenin Faaliyet Süresi ve Kara Geçiş Süresi Durumuna Yönelik Bulgular

\begin{tabular}{|c|c|c|c|c|c|c|}
\hline & \multicolumn{2}{|c|}{ Kayseri } & \multicolumn{2}{|c|}{ Yozgat } & \multicolumn{2}{|c|}{ Sivas } \\
\hline & Frekans & $\%$ & Frekans & $\%$ & Frekans & $\%$ \\
\hline \multicolumn{7}{|c|}{ İşletmenin Faaliyet Süresi } \\
\hline $0-1 \mathrm{y} 1 \mathrm{l}$ & 16 & 22,9 & 24 & 30,0 & 23 & 24,5 \\
\hline $1-3$ y1l & 38 & 54,3 & 45 & 56,25 & 53 & 56,4 \\
\hline $3-6$ yil & 14 & 20,0 & 9 & 11,25 & 16 & 17,0 \\
\hline 6 yildan fazla & 2 & 2,8 & 2 & 2,5 & 2 & 2,1 \\
\hline \multicolumn{7}{|c|}{ Kara Geçiş Süresi } \\
\hline $0-1$ yil & 31 & 44,3 & 45 & 56,25 & 46 & 48,9 \\
\hline $1-3$ y1l & 24 & 34,3 & 22 & 27,5 & 31 & 33,0 \\
\hline 3 yıldan fazla & 15 & 21,4 & 13 & 16,25 & 17 & 18,1 \\
\hline
\end{tabular}

İşletmenin faaliyet süresi ve kara geçiş süresi durumuna yönelik bulgular incelendiğinde, kadın girişimcilerin işletmelerinin 1-3 yıldır faaliyette olduğu belirlenmiştir. Bununla beraber Kayseri'de \%44,3, Yozgat'ta \%56,2 ve Sivas'ta \%48,9 oranında kadın girişimcilerin işletmelerinin 0-1 yılda kara geçtiği tespit edilmiştir. Bu oranlara göre kadın girişimciliğinin son yıllarda Anadolu şehirlerinde cazip bir meslek olarak artış gösterdiği söylenebilir.

Tablo 14: İşletmenin Sosyal Medya Hesabı Olma Durumuna Yönelik Bulgular

\begin{tabular}{|l|c|c|c|c|c|c|}
\hline & \multicolumn{2}{|c|}{ Kayseri } & \multicolumn{2}{c|}{ Yozgat } & \multicolumn{2}{c|}{ Sivas } \\
\hline & Frekans & $\mathbf{\%}$ & Frekans & \% & Frekans & \% \\
\hline Evet & 50 & 71,4 & 51 & 63,8 & 61 & 64,9 \\
\hline Hayır & 20 & 28,6 & 29 & 36,2 & 33 & 35,1 \\
\hline
\end{tabular}


İşletmenin sosyal medya hesabı olma durumuna yönelik bulgular incelendiğinde, Kayseri'de \%71,4, Yozgat'ta \%63,8 ve Sivas'ta \%64,9 oranında işletmelerin sosyal medya hesaplarının olduğu ifade edilmiştir. Bununla beraber tüm illerde toplamda kadın girișimcilerin yalnızca \%2,5'i sosyal medya pazarlamasında ajansla çalışmaktadır. Diğer kadın girişimciler sosyal medya hesapları ile kendileri ilgilenmektedir.

Tablo 15: İşletme Hakkında Genel Bilgilere Yönelik Bulgular

\begin{tabular}{|c|c|c|c|c|c|c|}
\hline & \multicolumn{2}{|c|}{ Kayseri } & \multicolumn{2}{|c|}{ Yozgat } & \multicolumn{2}{|c|}{ Sivas } \\
\hline & Frekans & $\%$ & Frekans & $\%$ & Frekans & $\%$ \\
\hline \multicolumn{7}{|c|}{ İşletmeyi Birinden Devir Alma Durumu } \\
\hline Evet & 10 & 14,3 & 11 & 13,8 & 15 & 16,0 \\
\hline Hayır & 60 & 85,7 & 69 & 86,2 & 79 & 84,0 \\
\hline \multicolumn{7}{|c|}{ Dış Ticaret Faaliyet Durumu } \\
\hline Evet & 8 & 11,4 & 4 & 5,0 & 8 & 8,5 \\
\hline Hayır & 62 & 88,6 & 76 & 95,0 & 86 & 91,5 \\
\hline \multicolumn{7}{|c|}{ Aile İşletmesi Olma Durumu } \\
\hline Evet & 8 & 11,4 & 12 & 15,0 & 10 & 10,6 \\
\hline Hayır & 62 & 88,6 & 68 & 85,0 & 84 & 89,4 \\
\hline \multicolumn{7}{|c|}{ Ortaklı Bir İşletme Olması } \\
\hline Evet & 11 & 15,7 & 10 & 12,5 & 11 & 11,7 \\
\hline Hayır & 59 & 84,3 & 70 & 87,5 & 83 & 88,3 \\
\hline \multicolumn{7}{|c|}{ Ortağın Aile Üyesi Olması } \\
\hline Evet & 8 & 11,4 & 9 & 11,2 & 8 & 8,5 \\
\hline Hayır & 62 & 88,6 & 71 & 88,8 & 86 & 91,5 \\
\hline \multicolumn{7}{|c|}{ Aile Fertlerinin İşletmede İstihdam Edilme Durumu } \\
\hline Evet & 19 & 27,1 & 18 & 22,5 & 25 & 26,6 \\
\hline Hayır & 51 & 72,9 & 62 & 77,5 & 69 & 73,4 \\
\hline
\end{tabular}

Girişimci kadınların Kayseri'de \%85,7'si, Yozgat'ta \%86,2'si ve Sivas'ta \%84'ü işletmeyi birinden devralmamıştır. Ayrıca işletmelerin \%91,8'inin dış ticaret faaliyeti bulunmamaktadır: Kayseri'de \%11,4, Yozgat'ta \%5 ve Sivas'ta \%8,5 oranında işletmeler diş ticarette uğraşmaktadır. Bu oranlara göre kadın girişimcilerin büyük çoğunluğunun yeni kurulmuş ve çok az bir kısmının dış ticarete yöneldiği söylenebilir.

Girişimcilerin Kayseri'de \%11,4'ü, Yozgat'ta \%15', Sivas'ta ise \%10,6's1 aile işletmesi değildir. Katılımciların tüm illerde toplamda \%2,5'i ikinci nesil ve \%11'i üçüncü nesil olduğunu ifade etmiştir. Bu oranlara göre aile işletmesi olan kişilerin daha düşük oranda girişimciliğe yöneldiği söylenebilir.

Girişimcilerin Kayseri'de \%15,7'si, Yozgat'ta \%12,5'i, Sivas'ta ise \%11,7'si ortaklı bir işletmedir. Katılımcıların tüm illerde toplamda \%2,5'inin ortağı 1.dereceden yakını, \%13'ünün ise akrabası olduğu belirlenmiştir. Kadın girişimcilerin düşük oranda da olsa ortaklığa ve genellikle akrabalarla ortaklığa yöneldiği söylenebilir.

Kadın girişimcilerin Kayseri'de \%27,1'i, Yozgat'ta \%22,5'i ve Sivas'ta \%26,6'sı aile fertlerini istihdam etmektedir. Katılımcıların tüm illerde toplamda \%2,5'i kardeşlerini ve \%5,7'si akrabalarını istihdam ettiğini belirtmiştir. Katılımcıların tüm illerde toplamda \%2,9'u kasada durduğunu ve \%2,9'u satış temsilcisi olarak görev yaptığını belirtmiştir. Bu oranlar tabloda düşük gibi görünse de kadın girişimcilerin akrabaları istihdam etme eğilimi gösterdiği söylenebilir. 
Tablo 16: İşletmede Geçirilen Zaman ve Çocuk Bakımına Yönelik Bulgular

\begin{tabular}{|c|c|c|c|c|c|c|}
\hline & \multicolumn{2}{|c|}{ Kayseri } & \multicolumn{2}{|c|}{ Yozgat } & \multicolumn{2}{|c|}{ Sivas } \\
\hline & Frekans & $\%$ & Frekans & $\%$ & Frekans & $\%$ \\
\hline \multicolumn{7}{|c|}{ İşletmede Aktif Olarak Geçirilen Zaman } \\
\hline Gitmiyor & - & - & 1 & 1,25 & 5 & 5,3 \\
\hline $1-3$ saat & 7 & 10,0 & 8 & 10 & 30 & 32 \\
\hline 4-6 saat & 32 & 45,7 & 37 & 46,25 & 49 & 52,1 \\
\hline 6 saatten fazla & 31 & 44,3 & 34 & 42,5 & 10 & 10,6 \\
\hline \multicolumn{7}{|c|}{ Aile Üyelerinden Destek Alma Durumu } \\
\hline Evet & 34 & 48,6 & 30 & 37,5 & 38 & 40,4 \\
\hline Hayır & 36 & 51,4 & 50 & 62,5 & 56 & 59,6 \\
\hline \multicolumn{7}{|c|}{ Aile Üyelerinden Destek Alınan Zaman } \\
\hline Hafta sonlar1 & 2 & 2,9 & 3 & 3,8 & 2 & 2,1 \\
\hline Haftada birkaç gün & 2 & 2,9 & 5 & 6,2 & 4 & 4,3 \\
\hline Her gün & 4 & 5,7 & 4 & 5,0 & 5 & 5,3 \\
\hline İhtiyaç duyduğum zamanlarda & 28 & 40,0 & 21 & 26,2 & 29 & 30,9 \\
\hline \multicolumn{7}{|c|}{ İște Olma Süresinde Çocuğun Bakımıyla İlgilenen } \\
\hline Eşim & 2 & 2,9 & 3 & 2,0 & 5 & 5,3 \\
\hline Eşimin Ailesi & 5 & 7,1 & 6 & 6,0 & 14 & 14,9 \\
\hline Ailem & 10 & 14,3 & 11 & 11,0 & 25 & 26,6 \\
\hline Bakıc1 & 9 & 12,9 & 10 & 12,0 & 10 & 10,6 \\
\hline Anaokulu/Kreş & 9 & 12,9 & 12 & 13,0 & 14 & 14,9 \\
\hline \multicolumn{7}{|c|}{ Çocuğu İşe Götürme Zorunluluğu } \\
\hline Evet & 24 & 34,3 & 21 & 26,2 & 30 & 31,9 \\
\hline Hayır & 20 & 28,6 & 24 & 30,0 & 28 & 29,8 \\
\hline
\end{tabular}

İşletmede geçirilen zaman ve çocuk bakımına yönelik bulgular incelendiğinde, Kayseri'de \%45,7, Yozgat'ta \%36 ve Sivas'ta \%46,8 oranında kadın girişimciler günde 4-6 saat arasında işletmede aktif zaman geçirmektedir. Kadın girişimcilerin kısa mesai saatlerinin nedeni aile üyelerine girişimlerini bırakmaları ya da destek almaları olarak ifade edilebilir. Kadın girişimcilerin Kayseri'de \%48,6, Yozgat'ta \%37,5 ve Sivas'ta \%40,4 oranında aile üyelerinden destek aldığı belirlenmiştir. Ayrıca Kayseri'de \%40, Yozgat'ta \%26,2 ve Sivas'ta \%30,9 oranında kadın girişimciler ihtiyaç duyduklarında destek almaktadırlar. Kadınların işte oldukları zamanlarda çocuğun bakımıyla ilgilenen kişi incelendiğinde, Kayseri'de \%14,3 ve Sivas'ta \%26,6 oranında kadınların aileleri ilgilenirken, Yozgat'ta \%13 oranında çocuklar anaokulu/kreşe gitmektedir. Kadın girişimcilerin Kayseri'de \%34,3, Yozgat'ta \%26,2 ve Sivas'ta \%31,9 oranında çocuklarını işe götürme zorunluluklarının olduğu ifade edilmiştir. Oranlara bakıldığında kadın girişimcilerin iş ve aile dengesini kurma noktasında önemli oranda aile desteği aldıkları görülmektedir. 
Tablo 17: Kadın Girişimci Olma Durumuna Yönelik Bulgular

\begin{tabular}{|c|c|c|c|c|c|c|}
\hline & \multicolumn{2}{|c|}{ Kayseri } & \multicolumn{2}{|c|}{ Yozgat } & \multicolumn{2}{|c|}{ Sivas } \\
\hline & Frekans & $\%$ & Frekans & $\%$ & Frekans & $\%$ \\
\hline \multicolumn{7}{|c|}{ Girişimci Olmayı Etkileyen Durum } \\
\hline Haneye ek gelir sağlamak & 32 & 45,7 & 33 & 41,3 & 35 & 37,2 \\
\hline Bağımsız çalışma isteği & 28 & 40,0 & 29 & 36,3 & 31 & 33,0 \\
\hline Ekonomik bağımsızlık isteği & 25 & 35,7 & 28 & 35,0 & 28 & 29,8 \\
\hline Sosyal ilişkileri geliştirmek & 23 & 32,9 & 25 & 31,3 & 25 & 26,6 \\
\hline Aile girişimini devam ettirmek & 2 & 2,9 & 4 & 5,0 & 4 & 4,3 \\
\hline Bir ticari fikri hayata geçirmek & 20 & 28,6 & 21 & 26,3 & 22 & 23,4 \\
\hline \multicolumn{7}{|c|}{ İşyeri Kurarken Ve Sonrasında Cinsiyet Ayrımına Uğrama Durumu } \\
\hline Evet & 32 & 45,7 & 28 & 35,0 & 43 & 45,7 \\
\hline Hayır & 38 & 54,3 & 52 & 65,0 & 51 & 54,3 \\
\hline \multicolumn{7}{|c|}{ Kadın Olarak İşyeri Açmanın Çevrede Yadırganma Durumu } \\
\hline Evet & 22 & 31,4 & 27 & 33,8 & 33 & 35,1 \\
\hline Hayır & 48 & 68,6 & 53 & 66,2 & 61 & 64,9 \\
\hline \multicolumn{7}{|c|}{ İşletme Açıldıktan Sonra Aileye Yeteri Kadar Vakit Ayıramadığını Düşünme Durumu } \\
\hline Evet & 38 & 54,3 & 47 & 58,8 & 55 & 58,5 \\
\hline Hayır & 32 & 45,7 & 33 & 41,2 & 39 & 41,5 \\
\hline \multicolumn{7}{|l|}{ Girişimci Olmanın En İyi Tarafı } \\
\hline Bağımsızlık & 32 & 45,7 & 30 & 37,5 & 43 & 45,7 \\
\hline Kariyer & 2 & 2,9 & 2 & 2,5 & 2 & 2,1 \\
\hline Özgüven & 13 & 18,6 & 15 & 18,8 & 15 & 16,0 \\
\hline Para Kazanmak & 4 & 5,7 & 6 & 7,5 & 6 & 6,4 \\
\hline Sosyal Statü & 17 & 24,3 & 25 & 31,2 & 25 & 26,6 \\
\hline Yeni Şeyler Öğrenmek & 2 & 2,9 & 2 & 2,5 & 3 & 3,2 \\
\hline
\end{tabular}

Kadın girişimci olma durumuna yönelik bulgular incelendiğinde, Kayseri'de $\% 45,7$, Yozgat'ta \%41,3 ve Sivas'ta \%37,2 oranında kadınların haneye ek gelir sağlamak için girişimcilik faaliyetlerine başladıkları ifade edilmiştir. İşyeri kurarken ve sonrasında cinsiyet ayrımına uğrama durumu incelendiğinde Kayseri'de \%45,7, Yozgat'ta \%35 ve Sivas'ta \%45,7 oranında kadınların cinsiyet ayrımına maruz kaldıkları belirlenmiştir. Kadın olarak işyeri açmanın çevrede yadırganma durumu incelendiğinde ise Kayseri'de \%31,4, Yozgat'ta \%33,8 ve Sivas'ta \%35,1 oranında kadınlar çevrelerinde yadırgandıklarını ifade etmişlerdir. Kadın girişimcilerin yarıya yakını ek gelir için girişimci olurken, yine yarıya yakını cinsiyet ayrımına maruz kaldıklarını, azımsanmayacak bir oranda kadın girişimcinin de çevrelerinde yadırgandıklarını ifade ettiği görülmüştür.

İşletme açıldıktan sonra aileye yeteri kadar vakit ayıramadığını düşünme durumu incelendiğinde Kayseri'de \%54,3, Yozgat'ta \%58,8 ve Sivas'ta \%58,5 oranında kadınların ailelerine yeteri kadar vakit ayıramadıkları tespit edilmiştir. Kadın girişimciler büyük oranda ailelerine vakit ayıramadıklarını ifade etmişlerdir. $\mathrm{Bu}$ da girişimcinin mesaisinin olmaması ve işletmesi ile ilgili her konuyla kendisinin ilgilenmek zorunda olması şeklinde ifade edilebilir.

Girişimci olmanın en iyi tarafı incelendiğinde ise Kayseri'de \%45,7, Yozgat'ta \%37,5 ve Sivas'ta \%45,7 oranında kadınlar bağımsız olma durumunun girişimci olmada en iyi taraf olduğunu ifade etmişlerdir. Bu oranlar da kadınların girişimci olma nedenlerinden biri olan bağımsız olma arzusunun bir yansıması olarak düşünülmektedir. 
Tablo 18: İşyerinin Kira Olma Durumu ve Karşılaşılan Zorluklara Yönelik Bulgular

\begin{tabular}{|c|c|c|c|c|c|c|}
\hline & \multicolumn{2}{|c|}{ Kayseri } & \multicolumn{2}{|c|}{ Sivas } & \multicolumn{2}{|c|}{ Yozgat } \\
\hline & Frekans & $\%$ & Frekans & $\%$ & Frekans & $\%$ \\
\hline \multicolumn{7}{|c|}{ İşyerinin Kira Olma Durumu } \\
\hline Evet & 41 & 58,6 & 49 & 61,2 & 55 & 58,5 \\
\hline Hayır & 29 & 41,4 & 31 & 38,8 & 39 & 41,5 \\
\hline \multicolumn{7}{|c|}{ İşyeri Kurarken Karşılaşılan Sorunlar } \\
\hline Cinsiyet ayrımcılı̆g 1 & 7 & 10,0 & 8 & 10,0 & 10 & 10,6 \\
\hline Güvensizlik & 5 & 7,1 & 6 & 7,5 & 8 & 8,5 \\
\hline Çevresel tepki & 9 & 12,9 & 11 & 13,8 & 12 & 12,8 \\
\hline $\begin{array}{l}\text { Devlet desteğinin } \\
\text { olmaması }\end{array}$ & 4 & 5,7 & 6 & 7,5 & 8 & 8,5 \\
\hline
\end{tabular}

Kadın girişimcilerin \%59,4'ü işyeri kirası ödemektedir. Bununla beraber \%4,5’i kira ödeme nedeniyle tasarruf yapamadığını ve \%2,9'u kirayı yüksek bulduğunu belirtmiştir. Kadın girişimcilerin önemli oranda kiralık işletmelerde faaliyet gösterdikleri görülmektedir.

\section{Sonuç}

$\mathrm{Bu}$ araştırmada Sivas, Kayseri ve Yozgat illerinde faaliyet gösteren kadın girişimcilerin ve işletmelerinin sahip olduğu özellikler incelenerek bu illerdeki kadın girişimcilerin profilleri belirlenmeye çalışılmıştır. Araştırma sonucuna göre Sivas, Kayseri ve Yozgat illerinde girişimci olarak faaliyet gösteren kadınların önemli bir kısmının işletmesi küçük ölçeklidir. Kadınların girişimcilik faaliyetlerine başlamalarında özellikle aileye maddi destek sağlama ve bağımsız çalışma isteği ön plana çıkmaktadır. Kadın girişimcilerin önemli bir bölümü özellikle çocuk bakımı açısından diğer aile üyelerinden destek almaktadır. Kadın girişimciler için toplumsal cinsiyet ayrımcılığının yanı sıra kredi desteği gibi maddi problemler ilk sıralarda yer almaktadır.

Genel olarak bakıldığında TR72 bölgesindeki kadın girişimcilerin büyük çoğunluğunun kadınlara özgü olarak nitelendirilen işlerde (restoran işletmeciliği, giyim mağazaları, ev yemekleri işletmesi vb.) ve kadınların ihtiyaçlarını karşılamaya yönelik hizmet sektörlerinde (kuaför, güzellik salonu vb.) ağırlıklı olarak yer aldıkları görülmektedir. Bölgesel olarak kadın girişimciliğinin sanayi sektöründen uzak bir girişimcilik faaliyeti sergilediği söylenebilir. Bunun nedeninin; araştırma yapılan illerde sanayi ve üretim alanındaki erkek egemen girişimcilik yapısının olduğu düşünülmektedir.

Araştırmaya katılan kadın girişimcilerin yaşları 20 ile 40 arasında değişmekte olup, yaş ortalaması 28'dir.Bölgedeki kadın girişimcilerin büyük çoğunluğunun lise mezunu olduğu görülmektedir. Bu durum bölgedeki kadın girişimcilerin daha genç yaş aralığında olmasının sebebi olarak düşünülebilir. Yine her üç ilde kadın girişimcilerin büyük çoğunluğunun evli olması, girişimcilik konusunda eşlerinden destek aldıkları şeklinde yorumlanabilir.

Her üç ilde de kadınların girişimcilik öncesinde belli bir iş deneyimi olmadığı ve girişimcilik öncesinde giderlerinin gelirlerinden daha fazla olduğu tespit edilmiştir. Buna göre kadınların girişimcilik faaliyetlerine yönelmelerinin nedeni istedikleri gibi harcama yapabilecekleri ekonomik gelire sahip olma ve aile bütçesine katkı sunma olarak ifade edilebilir. Kadın girişimcilerin girişimcilik sonrası aylık gelir durumuna yönelik bulgular incelendiğinde ise tüm illerdeki kadın girişimcilerin girişimcilik sonrasında gelirinin daha fazla olduğu tespit edilmiştir. Bu oranlar kadınların girişimcilik faaliyetlerinde ekonomik olarak önemli katkılar sağladığını göstermektedir. Ankete katılan kadın girişimcilerin yarısından fazlasının ailesinde girişimci olmadığı görülmüştür. Bu nedenle kadın girişimcilerin aileleri için 
örnek teşkil edebileceği ve girişimcilik kültürünün yaygınlaşmasında rol oynayabileceği söylenebilir.

Kadın girişimcilerin mesleki eğitim, giriş̧imcilik eğitimi, girişimcilik faaliyetinde bulunma durumuna yönelik bulgular incelendiğinde, kadınların mesleki eğitim kurslarına ve girişimcilik eğitimine katıldığı tespit edilmiştir. İşletmeyi açmadan önce girişimcilik faaliyetinde bulunma durumuna bakıldığında, tüm illerde büyük oranda işletmeyi açmadan önce girişimcilik faaliyetinde bulunulmadığı görülmüştür. $\mathrm{Bu}$ açıdan değerlendirildiğinde kadınların girişimcilik deneyimleri olmadan girişimcilik faaliyetlerine yönelmelerinde, kadın girişimcilere yönelik teşviklerin ve bu teşvikler nedeniyle aile üyelerinin desteğinin etkisi olduğu söylenebilir.

KOSGEB desteği ve kredi/teşvik kullanma durumuna yönelik bulgular incelendiğinde, kadın girişimcilerin KOSGEB desteğinden faydalanmadığı, kredi ve teşvik kullanılmadığı tespit edilmiştir. $\mathrm{Bu}$ sonuçlara bakıldığında kadın girişimcilerin yarısının farklı nedenlerden dolayı teşvik ve kredi kullanımına sıcak bakmadığı söylenebilir.

İşletmede geçirilen zaman ve çocuk bakımına yönelik bulgular incelendiğinde, kadın girişimciler günde ortalama 4-6 saat arasında işletmede aktif zaman geçirmektedirler. Kadın girişimcilerin kısa mesai saatlerinin nedeni aile üyelerine girişimlerini bırakmaları ya da destek almaları olarak ifade edilebilir. Genel olarak bakıldığında kadın girişimcilerin iş ve aile dengesini kurma noktasında önemli oranda aile desteği aldıkları görülmektedir. Ayrıca kadın girişimcilerin yarıya yakını cinsiyet ayrımcılığına maruz kaldıklarını, azımsanmayacak bir oranda kadın girişimcinin ise çevrelerinde yadırgandıklarını ifade ettiği görülmüştür.

Kadın girişimcilerin farklı sektörlerde de girişim faaliyetlerinde aktif olarak yer alabilmesi için kadın girişimciliğinin teşviki ve desteklenmesi konusunda stratejilerin ve politikaların üretilmesi ve geliştirilmesi gerekmektedir. Ayrıca kadınların geleneksel sayılan meslek alanlarının dışında da faaliyette bulunabileceği alanların oluşturulup bu alanlarda kadınlara eğitim verilerek teşvik edilmesi, kadınların sanayi gibi üretim alanlarında girişimciliğe yönelmelerini sağlayabilir. Girişimcilik konusunda kadınların desteklenmesi, istihdamda yaratacağı etkiler ve ekonomik alanda yaratacağı sonuçlar ile hem bölgesel hem de ülke ekonomisi için büyük önem taşımaktadır. Kadınların girişimcilik alanında daha aktif rol alması ile hem ekonominin daha etkin hale geleceği hem de kadın erkek arasındaki cinsiyet eşitsizliğinin azalacağı ve bölgedeki ataerkil yapının kırılacağı düşünülmektedir. Ayrıca kadın girişimciliğine yönelik destekler sadece iş kurma aşamasında değil, işi kurduktan sonra girişimcilik faaliyetini sürdürürken de devam ettirilmelidir. Bu doğrultuda kadın girişimcilere yönelik eğitimlerle kadın girişimciliğine daha dinamik bir yapı kazandırılmalıdır.

Çalışmanın yapıldığı Sivas, Kayseri, Yozgat illerinde çalışma sonuçlarının benzerlik gösterdiği görülmüştür. Bunun nedeni her üç ilin sosyo-kültürel yapı itibariyle birbirine yakın özellikler göstermesidir. Her üç il için çalışmanın örneklemi genişletilerek yapılacak çalışmalarda daha genellenebilen sonuçlara ulaşılabilir. Ayrıca benzer çalışmalar Anadolu'nun farklı illerinde ve kadın girişimciliğinin yoğun olduğu büyükşehirlerde yapılarak ortaya çıkan sonuçlar ile mikro düzeyde il ve bölgelerin, makro düzeyde ise ülkedeki kadın girişimcilerin profili ortaya koyulabilir. 


\section{Kaynakça}

Alpşahin, U. (2011). Kadın Girişimcilerin Başarı Faktörleri: Farklılık Yaratan Stratejilerin Çözümlenmesi, Yayınlanmamış doktora tezi, Çanakkale 18 Mart Üniversitesi, Çanakkale.

Aydın, D. ve Çam, M.S. (2016). Bilgi Toplumu Dönüşümünde Türkiye'de Kadın Olmak. DumlupinarUniversityJournal of SocialScience/Dumlupinar Üniversitesi Sosyal Bilimler Dergisi. Özel Sayı, 224-247.

Ballı Koca, A. (2015). Duygusal zeka, stresle başa çıkma yöntemleri, liderlik davranışları ve işletme performansı arasındaki ilişkinin analizi: Kadın girişimciler üzerine bir çalışma. Çukurova Üniversitesi / Sosyal Bilimler Enstitüsü. Doktora Tezi.

Başol, O. (2010). Girişimci Kadın ve Erkeklerin Başarı Algısındaki Farklılıklar: Küçük Ölçekli İşletmelerde Bursa İli Örneği. Yüksek Lisans Tezi.

Bedük A., Eryeşil K. ve Oğuz H. (2016). Kadın ve Erkek Girişimcilerin Algılama Farklılıkları. Selçuk Üniversitesi Sosyal Bilimler Meslek Yüksek Okulu Dergisi, 19, 1-15.

Goyal, P. ve Yadav, V. (2014). To be or not to be a womanentrepreneur in a developingcountry. PsychosociologicalIssues in Human Resource Management, 2(2), 68-78.

Goyal, M., ve Parkash, J. (2011). Womenentrepreneurship in India-problemsandprospects. International journal of multidisciplinaryresearch, 1(5), 195-207.

Heilman, M. E. ve Chen, J. (2003). Entrepreneurship as a solution: theallure of selfemploymentforwomenandminorities. Human Resource Management Review, 13(2), 347364.

Güney, S. (2006). 'Kadın Girişimciliğine Genel Bir Bakış' http://acikerisim.lib.comu.edu.tr:8080/xmlui/bitstream/handle/COMU/971/Semra_Gune y_Makale.pdf?sequence $=1 \&$ isAllowed $=\mathrm{y}$

Ögüt, A. (2006). Türkiye'de kadın girişimciliğin ve yöneticiliğin önündeki güçlükler: Cam tavan

sendromu. http://acikerisim.lib.comu.edu.tr:8080/xmlui/bitstream/handle/COMU/973/Adem_Ogut Makale.pdf?sequence $=1 \&$ isAllowed $=\mathrm{y}$

Özyol, A. (2015). Eşitlik İş Demektir. Kalkınmada Anahtar Verimlilik Dergisi. 315, https://anahtar.sanayi.gov.tr/tr/news/esitlik-is-demektir/1971

Rao, V.;Venkatachalm, A. ve Joshı H.G. (2013) "A Study On EntrepreneurialCharacteristicsAndSuccess Of WomenEntrepreneurs Operating FashionAndApparel Business", AsianJournal Of Management SciencesAndEducation, 2(2): 136-147.

Soysal, A. (2010a). Kadın girişimcilerin özellikleri, karşılaştıkları sorunlar ve iş kuracak kadınlara öneriler: Kahramanmaraş ilinde bir araştırma. Eskişehir Osmangazi Üniversitesi İktisadi ve İdari Bilimler Fakültesi Dergisi, 5(1), 71-95.

Soysal, A. (2010b). Türkiye'de Kadın Girişimciler: Engeller Ve Fırsatlar Bağlamında Bir Değerlendirme. Ankara Üniversitesi SBF Dergisi, 65(01), 083-114.

Şekerler, H. (2006). Kadın Girişimciler, Karşılaştıkları Sorunlar Ve Bu Sorunlara Yönelik Çözüm Önerileri. Yayınlanmamış Yüksek Lisans Tezi, Dumlupınar Üniversitesi, Kütahya.

Yıldırım, İ. ve Çıkmaz, E. (2016). Kadın Girişimcilerin, Kamu Kurum ve Kuruluşlarından Destek Alma Sürecinde Karşılaştıkları Sorunlar: Gaziantep İlinde Nitel Bir Değerlendirme. Journal of International Social Research, 9(47):977-985. 